\title{
On automatic loss of citizenship: Looking into the Alvin Teage Jalloh v Olubanke King-Akerele case through the lens of international law
}

\section{Arafat Ibnul Bashar ${ }^{1}$}

Accepted: 19 March 2021 / Published online: 15 April 2021

(c) O.P. Jindal Global University (JGU) 2021

\begin{abstract}
Matters regarding citizenship fall in the domain of domestic law, and international law has very little to contribute in this regard. But over the years, the all-pervading grasp of international human rights has not let the matter of citizenship go untouched as it has pondered over the issues of the right to nationality, statelessness, and dual citizenship due to the substantial human rights implications stemming from them. Although the decision of the Supreme Court of Liberia in the case of Alvin Teage Jalloh v Olubanke King-Akerele was based entirely on its constitutional norms, the findings of the Court reflect the stand of international law in this matter. Due to the massive legal, social, and political implications of the status of citizenship, the latter has been gradually gaining momentum in the realm of international law. Both Myanmar's Nationality Law of 1982 and India's National Register of Citizens (NRC) are shrouded in controversy due to their impact on the human rights of a considerable human population. The issue of the automatic loss of citizenship can snowball into a 'leviathan' in the contemporary politics of different states. The present case note looks into how this issue was handled by the Liberian Supreme Court and evaluates the decision on the scales of the established principles of international law.
\end{abstract}

Keywords Citizenship · Automatic loss of citizenship · Procedural due process · Arbitrary deprivation of nationality $\cdot$ International law

I don't need to be a global citizen, 'Cause I'm blessed by nationality ...

- Bad Religion ${ }^{1}$

\footnotetext{
1 Opening lines from the song 'American Jesus' sung by the American punk band Bad Religion. Album: Recipe for Hate (1993).)

Arafat Ibnul Bashar

a.ibnul.b@gmail.com; arafat.law@std.cu.ac.bd

1 Department of Law, University of Chittagong, Chattogram, Bangladesh
} 


\section{Introduction}

Citizenship is undoubtedly the most essential status a state can confer on an individual. The concept of citizenship is concerned with the rights and status of an individual. $^{2}$ Without the citizenship of a country, an individual turns into a stateless person, devoid of any rights and legal protection, and a menace to all countries at large. Stripping citizenship away from a portion of the population and turning them stateless is a calculated tactic that is being used by many despotic regimes to discriminate against and oppress people based on their political ideology, race, religion, gender, sexual orientation, etc. And when a considerable number of people are expelled or barred from the country, they become a problem for other states. Statelessness can not only result in massive violation of human rights but also create problems in international politics. Thus, it is not surprising that international law is concerned with the mechanisms and practices that may lead to such consequences as the essence of international law has always been the concern for human beings. ${ }^{3}$ Automatic loss of citizenship, an issue dealt with by the Liberian Supreme Court in the case of Alvin Teage Jalloh v Olubanke King-Akerele, is one such discriminatory practice. Although the ruling was based on the constitutional norms of Liberia, it needs to be brought under the scrutiny of international law as such discriminatory practices are quite common in Africa and also in other parts of the world.

\section{Facts of the case}

The petitioner, Alvin Teage Jalloh, was a natural-born Liberian citizen and residing in the US. He requested a travel document in order to travel to Liberia but was denied by the Liberian Embassy in Washington, D.C. The ground for the denial was that since the petitioner had acquired the citizenship of the US, he now required a non-immigrant visa to travel to Liberia, pursuant to the Aliens and Nationality Law. The petitioner's contention was that such a decision of the embassy and enforcement of sections 22.1 and 22.2 of the Aliens and Nationality $\mathrm{Law}^{4}$ by the government was a violation of the due process clause of the Liberian Constitution, ${ }^{5}$ and that the provisions stood repealed. The Government of the Republic of Liberia, being the respondent in this case, contended that the petitioner lacked the legal standing to challenge the legality of the Act, and that neither was the Act repealed nor was it in violation of the due process clause of the Constitution. The Court was of the opinion

\footnotetext{
${ }^{2}$ Linda Bosniak, 'Citizenship Denationalized' (2000) 7(2) Indiana Journal of Global Legal Studies 447, 448; Linda Bosniak, 'Citizenship' in Peter Cane and Mark Tushnet (eds), The Oxford Handbook of Legal Studies (Oxford University Press 2005) 190; Alvin Teage Jalloh v Olubanke King-Akerele, Petition In Re: Constitutionality of Sections $22.1 \& 22.2$ of the Aliens and Nationality Law, Supreme Court of the Republic of Liberia, 7.

${ }^{3}$ Malcolm N Shaw, International Law (6th edn, Cambridge University Press 2008) 258.

${ }^{4}$ Title 4 of the Liberian Code of Laws, Aliens and Nationality Law (approved 15 May 1973, amendments approved 9 May 1974).

${ }^{5}$ Constitution of the Republic of Liberia, 1986, article 20(a).
} 
that since the citizenship rights of the petitioner had suffered or were in danger of suffering, he had the standing to contest the constitutionality of the above-mentioned provisions. ${ }^{6}$ The Court agreed with the petitioner and concluded that section 22.2 of the Act stood repealed after the Constitution of Liberia came into force. Article 95(a) had repealed section 22.2 of the Act, due to being in conflict with the due process requirement under article 20 (a) of the Constitution. ${ }^{7}$

\section{Rationale of the decision}

In this particular case, the Court was tasked with scrutinising the constitutionality of sections 22.1 and 22.2 of the Aliens and Nationality Law of Liberia, which stripped the petitioner of his citizenship. Section 22.1 of the Act mentioned acts which would cause the loss of citizenship, among which one was obtaining naturalisation in a foreign state through an application, ${ }^{8}$ which the petitioner actually did. Section 22.2 further stated that loss of citizenship under section 22.1 shall result solely from the performance of such acts or fulfilment of the conditions set out in the section and no proceedings shall be taken by the government to nullify or cancel such citizenship. Although the petitioner contested the constitutionality of both these sections, the Court found only section 22.2 to be in violation of the Constitution. ${ }^{9}$ The Court found that the section was in conflict with article 20(a) of the Constitution, which requires that no deprivation of life, liberty, security, privilege, right, etc., should be made without any hearing and a judgment based on the canons of the Constitution and in accordance with the due process of law. ${ }^{10}$ In short, the automatic loss of citizenship without judicial proceedings was in violation of the due process requirement of the Constitution. ${ }^{11}$ The Court emphasised the requirement of due process by stating how it had been at the core of Liberia's constitutional jurisprudence since the inception of the country and had not been compromised even during the military coup and civil war. ${ }^{12}$ The Court took a peek into the Immigration and Nationality Act of the US. ${ }^{13}$ The Liberian law contained provisions that were an exact replica of the US provisions, with some minor variations. ${ }^{14}$ The said provisions were challenged in Afroyim v Rusk, ${ }^{15}$ where the Supreme Court of the US was of the opinion that such automatic loss of citizenship was unconstitutional and unenforceable. ${ }^{16}$

\footnotetext{
${ }^{6}$ Alvin Teage Jalloh v Olubanke King-Akerele (n 2) 4.

7 Ibid. 9.

8 Aliens and Nationality Law (n 4) section 22.1(a).

${ }^{9}$ Alvin Teage Jalloh v Olubanke King-Akerele (n 2) 5.

10 Ibid.

11 Ibid. 6.

12 Ibid. 7.

13 Immigration and Nationality Act of 1965 (US).

14 Alvin Teage Jalloh v Olubanke King-Akerele (n 2) 7, 8; also see sections 401 and 408 of the Immigration and Nationality Act of 1965 (US).

15 Afroyim v Rusk 387 U.S. 253 (1967).

16 Alvin Teage Jalloh v Olubanke King-Akerele (n 2) 8.
} 
The Court observed that the judiciary of the US, the country upon whose law the particular law of Liberia had been fashioned, had reached the conclusion that depriving a person of citizenship without any due process was unconstitutional. ${ }^{17}$ Thus, echoing the will of the framers of the Constitution of Liberia and its citizens who had voted for and adopted it, the Court held that the loss of citizenship solely on account of the performance by a citizen of acts or fulfilment of the conditions specified in section 22.1 without the institution of any proceedings by the government was in conflict with and repugnant to the due process clause under article 20(a) of the 1986 Constitution, and was declared null and void without any force and effect of law. $^{18}$

\section{Implications of the judgment}

Liberia has been a country of dual citizens from its inception. ${ }^{19}$ Founded by the freed slave settlers from America, and the recaptured slaves from the Congo Basin, and the native African-Liberians, both the natives and the settlers have continued to hold dual citizenship. ${ }^{20}$ Since the foundation of Liberia can be traced back to dual citizenship holders, ${ }^{21}$ the institution of dual citizenship can be deemed to be quite a common phenomenon. But the contested provisions restricted citizens from holding dual citizenship. As the Court has not touched section 22.1 of the Aliens and Nationality Law, the citizens of Liberia who obtain naturalisation in a foreign state or express their allegiance to or participate in the political process of another country may still lose their citizenship. But due to the declaration of section 22.2 as null and void, such loss of citizenship will only take place after there is a hearing by a court or any other administrative agency. In short, automatic loss of citizenship is no longer operational in Liberia. The decision has, to some extent, opened the door to dual nationality through naturalisation.

While the matter was before the Court, the legislature of Liberia proposed a constitutional referendum which, among other things, sought to repeal by implication section 22.1 of the Aliens and Nationality Law and thus allow all Liberians the right to acquire another nationality without the loss of their citizenship. ${ }^{22}$ The proposition, besides removing the barrier to acquiring foreign nationality, also disqualified citizens with dual citizenship from occupying certain elected national and public service positions including Chief Justice and Associate Justice of the Supreme Court,

\footnotetext{
17 Ibid. 9.

18 Ibid.

19 'OPINION-Liberia: An Analysis of the Sherman's Dual Citizenship Bill and the Revival of Apartheid' (African Star, 12 May 2018). https://www.africanstar.org/opinion-liberia-an-analysis-of-the-sherm ans-dual-citizenship-bill-and-the-revival-of-apartheid/. Accessed 20 November 2020.

20 Ibid.

21 Ibid.

22 'The Supreme Court Ruling in the Jalloh Case and "Proposition One" Are Entirely Different' (Liberian Observer, 28 October 2020). https://www.liberianobserver.com/opinion/the-supreme-court-rulingin-the-jalloh-case-and-proposition-one-are-entirely-different/\#_ftn1. Accessed 22 November 2020.
} 
ministers and deputy ministers, ambassadors, Chief of Staff and Deputy Chief of Staff of the Armed Forces, etc. ${ }^{23}$ As of November 2020, the referendum remains cancelled by the Supreme Court due to a procedural issue. ${ }^{24}$

\section{Citizenship and international law}

Citizenship has always been known to be outside the scope of international law. Citizenship, for the most part, has been related to the sovereignty of states. ${ }^{25}$ Matters regarding nationality ${ }^{26}$ only came within the scope of international law when there was a conflict of laws, and a court or tribunal had to decide which nationality law was to be applied in a particular dispute. ${ }^{27}$ Although international law has never interfered with the mechanisms which states devise to confer or cancel citizenships, the consequences of such decisions have always been the concern of international law. Matters regarding diplomatic protection and investor-state disputes, which concern the nationality of an individual, have been common issues in international courts and tribunals. Similarly, any issue regarding citizenship can become a concern of international law if it is likely to affect human rights and international politics.

In the case of the Nationality Decrees Issued in Tunis and Morocco, ${ }^{28}$ the Permanent Court of International Justice was of the opinion that although issues of nationality are not regulated by international law, the right of a state can be restricted by obligations which it has undertaken towards other states and that jurisdiction which belongs solely to the state can be limited by rules of international law. ${ }^{29}$ The Hague Convention on Certain Questions relating to the Conflict of Nationality Laws, 1930 - arguably the first international instrument that dealt with the issue of nationality - while providing for freedom of states to determine their own nationality laws,

\footnotetext{
23 Ibid.; see the Liberia Official Gazette on the National Referendum - 2020 (vol. 19, no. 52, 8 October 2019). https://www.emansion.gov.lr/doc/Official_National_Referendum_2020_20191015_1.pdf. Accessed 27 February 2021.

24 Reuters, 'Liberian Court Cancels Referendum on Presidential Terms and Dual Citizenship' (News 18, 19 November 2020). https://www.news18.com/news/world/liberian-court-cancels-referendum-on-presi dential-terms-and-dual-citizenship-3096563.html. Accessed 22 November 2020.

25 Peter J Spiro, 'A New International Law of Citizenship' (2011) 105(4) American Journal of International Law 694, 698.

26 In this article, the terms 'nationality' and 'citizenship' are used interchangeably to imply the legal bond that exists between an individual and a state. While 'nationality' implies the international aspect, 'citizenship' is associated with municipal law. See, for example, Paul Weis, Nationality and Statelessness in International Law (Sijthoff \& Noordhoff 1979) 4-5.

27 Ruth Donner, The Regulation of Nationality in International Laws (2nd edn, Brill \& Nijhoff 1994) 17.

28 Nationality Decrees Issued in Tunis and Morocco (French Zone) Advisory Opinion, (1923) PCIJ Series B no. 4.

29 Ibid. [41].
} 
required that such laws be consistent with international conventions, international custom, and the principles of law generally recognised with regard to nationality. ${ }^{30}$ The Universal Declaration of Human Rights (UDHR) later established the right to a nationality for every individual and also provided the right against arbitrary deprivation of nationality. ${ }^{31}$ The provision was a reaction to the problem of statelessness created due to the significant number of refugees and displaced persons after the First and Second World Wars. ${ }^{32}$ Subsequently, the 1954 Convention relating to the Status of Stateless Persons and the 1961 UN Convention on the Reduction of Statelessness were adopted to realise the commitments under article 15 of the UDHR. As avoidance of statelessness became a general principle of international law, ${ }^{33}$ regulation of citizenship became a concern of international law. Besides statelessness, the other principles of international law that restrict the freedom of states to regulate their own nationality include the requirement to grant nationality to children born in the territory who would otherwise be stateless ${ }^{34}$ discrimination in granting or revoking citizenship based on race, colour, or ethnic origin, ${ }^{35}$ gender, ${ }^{36}$ disability, ${ }^{37}$ or political opinion, ${ }^{38}$ maintaining due process in the granting and revoking of citizenship, etc.

International law has always interfered with a country's internal legislation when there have been concerns about human rights. The status of citizenship deeply affects a person's enjoyment of human rights as it assures a range of rights and privileges to its holder. Not all rights that are recognised by the constitution of a country are equally applicable to those who are non-citizens. A state can restrict or severely curtail the right to liberty, right to work, right to freedom of movement, right to an effective remedy, and many other fundamental human rights of an alien. A state is only responsible for the full protection of its citizens, and regarding non-citizens, its responsibilities are scaled down to a large extent. Aliens are still endowed with some

\footnotetext{
${ }^{30}$ Convention on Certain Questions relating to the Conflict of Nationality Law, 13 April 1930, League of Nations Treaty Series, vol. 179, p. 89, No. 4137, article 1.

${ }^{31}$ Universal Declaration of Human Rights, 10 December 1948, General Assembly Resolution 217 A (III), article 15 .

32 Trudy Huskamp Peterson, 'The Universal Declaration of Human Rights: An Archival Commentary' (International Council on Archives - Human Rights Working Group 2018) 37-39.

${ }^{33}$ United Nations General Assembly, Human Rights Council, Annual Report of the United Nations High Commissioner for Human Rights and Reports of the Office of the High Commissioner and the SecretaryGeneral, Arbitrary Deprivation of Nationality: Report of the Secretary-General, A/HRC/10/34, 26 January 2009 [51].

${ }^{34}$ United Nations General Assembly, Convention on the Rights of the Child (20 November 1989), UNTS vol. 1577, p. 3, article 7; UN Human Rights Committee, CCPR General Comment No. 17: Article 24 (Rights of the Child), 7 April 1989 [8].

${ }^{35}$ United Nations General Assembly, International Convention on the Elimination of All Forms of Racial Discrimination, 21 December 1965, United Nations Treaty Series, vol. 660, p. 195, article 5(d) (iii).

${ }^{36}$ United Nations General Assembly, Convention on the Elimination of All Forms of Discrimination Against Women, 18 December 1979, United Nations Treaty Series, vol. 1249, p. 13, article 9.

${ }^{37}$ United Nations General Assembly, Convention on the Rights of Persons with Disabilities: Resolution Adopted by the General Assembly, 24 January 2007, A/RES/61/106, article 18.

${ }^{38}$ International Covenant on Civil and Political Rights, 16 December 1966, UNTS, vol. 999, article 2(1).
} 
fundamental human rights as abstaining from such will result in deterioration of diplomatic ties with the individual's state. States can provide protection to their citizens in foreign lands through diplomatic protection, and any state injuring an alien might be compelled to provide reparation. But such is not the case for stateless persons as they are not protected by the state of their nationality. In fact, apart from morality, there is no restriction on states to abstain from maltreating stateless individuals. ${ }^{39}$ The case of Ahmed Al-Kateb, a Palestinian born in Kuwait, is particularly relevant. ${ }^{40} \mathrm{He}$ was denied a temporary protection visa and detained in Australia due to not meeting the requirements of refugee status. Denied a visa and not being accepted back by either Kuwait or Gaza, Al-Kateb became stateless and was detained indefinitely. The High Court of Australia later held that his indefinite detention, i.e., indefinite detention of a stateless person, was lawful. At the moment, most stateless people are deprived of health care and other necessary protections that should be given by a state to its citizens in the midst of the Covid-19 pandemic. $^{41}$

\section{Due process of law for avoiding arbitrary deprivation of citizenship}

Following the UDHR, arbitrary deprivation of nationality has been explicitly forbidden in many other notable regional instruments. ${ }^{42}$ Besides that, every other document that provides for the right to nationality, by implication, prohibits arbitrary deprivation of nationality, ${ }^{43}$ as doing so interferes with the enjoyment of their right to nationality. The stance of international law against the arbitrary deprivation of nationality is due to its impact on the enjoyment of human rights. ${ }^{44}$ Arbitrariness in terms of revocation of nationality refers to the revocations that are not provided by the law, are irrational or unreasonable, or do not comply with procedural requirements, or do not conform to the standards of international law like legitimate purpose, proportionality, or non-discrimination. Arbitrary deprivation of nationality strips an individual's citizenship without proper justification and places that

\footnotetext{
${ }^{39}$ L Oppenheim, International Law (4th edn, Longmans, Green, and Co. 1928) 522.

40 Al-Kateb v Godwin (2004) HCA 37, (2004) 219 CLR 562.

41 See UN High Commissioner for Refugees, The Impact of COVID-19 on Stateless Populations: Policy Recommendations and Good Practices, 11 May 2020.

42 European Convention on Nationality, 6 November 1997, ETS 166, article 4; Organization of American States, American Convention on Human Rights, 'Pact of San Jose', Costa Rica, 22 November 1969, article 20; ASEAN Human Rights Declaration, 18 November 2012, article 18; League of Arab States, Arab Charter on Human Rights, 15 September 1994, article 24.

43 United Nations General Assembly, Human Rights Council, Annual Report of the United Nations High Commissioner for Human Rights and Reports of the Office of the High Commissioner and the SecretaryGeneral, Human Rights and Arbitrary Deprivation of Nationality: Report of the Secretary-General, A/ HRC/13/34, 14 December 2009 [21].

44 See, for example, United Nations General Assembly, Human Rights Council, Annual Report of the United Nations High Commissioner for Human Rights and Reports of the Office of the High Commissioner and the Secretary-General, Human Rights and Arbitrary Deprivation of Nationality: Report of the Secretary-General, A/HRC/19/43, 19 December 2011.
} 
individual in a disadvantaged situation regarding proper enjoyment of human rights and fundamental freedoms, ${ }^{45}$ which hampers that individual's 'social integration'. In order to avoid arbitrary deprivation of citizenship, the requirement of due process of law is an absolute necessity. From clause 39 of the Magna Carta to article 20 of the Constitution of Liberia, the requirement of a hearing in order to deprive persons of their rights and privileges has been enshrined in every constitution and bill of rights. It is universally accepted as a must when the rights or privileges of an individual are under scrutiny. Emphasising the importance and antiquity of this principle, Fortescue $\mathrm{J}$ stated in $R v$ University of Cambridge, ${ }^{47}$ '...even God himself did not pass sentence upon Adam, before he was called upon to make his defence. ${ }^{48}$

Stripping a person of any right or privilege without hearing their side of the story is a violation of natural justice. States are expected to adhere to minimum procedural standards when the matter of nationality is at stake in order to avoid arbitrary decisions. ${ }^{49}$ International law does not impose any requirement or restriction when it comes to modes of acquisition or revocation of citizenship but obliges states to maintain due process of law while doing so. Many countries allow for the revocation of citizenship at the discretion of a minister and without appeal to an independent tribunal, or provide no right to challenge such a decision. ${ }^{50}$ The authority to revoke citizenship has been used by different African governments to serve political purposes, such as silencing a troublesome critic or someone who is running for election. ${ }^{51}$ The due process of law requirement enjoins states to revoke citizenship on predetermined criteria that should not be vague, ensure that such revocation is based upon a judgment of an independent court or tribunal, and that reasons for such a decision are furnished preferably with a right to appeal. The essence of the concept of 'due process of law' is the avoidance of arbitrariness. ${ }^{52}$ Procedural due process cannot be compromised even if the state is at war. ${ }^{53}$ Without due process safeguards, the authority to revoke citizenship lies solely in the hands of the executive, which may be politically motivated in making such decisions. Having procedural checks at every step ensures that any revocation is in full conformity with law and rationality. Only a decision taken through proper procedural mechanisms can ensure a lawful outcome. While it is not obligatory to abide rigidly by procedural steps in every case, the minimum requirements, which if not followed may result in an unjust decision, such as providing the opportunity to be heard, to defend oneself,

\footnotetext{
45 Ibid. [47].

46 See also UN Human Rights Council, Resolution 10/13, Human Rights and Arbitrary Deprivation of Nationality, 26 March 2009, article 6; UN Human Rights Council, Resolution 7/10, Human Rights and Arbitrary Deprivation of Nationality, 27 March 2008, article 6.

$47 R$ University of Cambridge (1723) 1 Str 557.

48 Ibid. 567.

49 UN Human Rights Council, Arbitrary Deprivation of Nationality: Report of the Secretary-General, 26 January 2009 (n 33) [43].

50 Bronwen Manby, Citizenship Law in Africa: A Comparative Study (2nd edn, Open Society Foundations 2016) 10.

51 Ibid. 10-11.

52 Mahmudul Islam, Constitutional Law of Bangladesh (3rd edn, Mullick Brothers 2012) 235.

53 See, for example, Hamdi v Rumsfeld 542 US 507 (2004).
} 
etc., must never be dispensed with. Even in cases where the citizenship is revoked by an express, informed, and voluntary renunciation, it is incumbent upon the state to furnish an official notice or statement that clearly mentions the date from which the revocation is to take place. Besides avoiding the practices that may result in arbitrary deprivation of nationality, it can also be argued that the due process requirement puts states under an obligation to provide effective remedies for those who have been arbitrarily deprived of their nationality, which may include the restoration of nationality, correction of registries, etc. ${ }^{54}$

\section{Why automatic loss of citizenship should not be tolerated}

In this particular case of Alvin Teage Jalloh v Olubanke King-Akerele, the application of section 22.2 of the Aliens and Nationality Law of Liberia resulted in the automatic loss of citizenship, i.e., citizenship was revoked through the performance of the acts or fulfilment of the prescribed conditions in section 22.1 of the law, without the government having to initiate any procedures. The application of the provision subjected Alvin Teage Jalloh to the immigration law, having lost the right to enter his own country. As he had already acquired American citizenship, there was no risk of statelessness. But the automatic loss of citizenship, being devoid of due process of law, causes arbitrary deprivation of nationality and may run the risk of an individual becoming stateless, and thus has scope to result in massive violations of human rights. The tool of automatic loss of citizenship could easily be used by autocrats to 'otherise' a specific portion of the population based on political opinion, race, religion, gender, sexual orientation, or any other differential criteria, which may be totally irrelevant to the status of citizenship. The legal bond entailed by citizenship requires an individual to show allegiance towards the state. A state provides protection and a huge array of rights to its citizens in exchange for their continued allegiance towards the state and its laws and norms. States can also, in certain situations, revoke the status of citizenship, thus withdrawing all such protection and privilege. But such revocation should be made only when the citizen is no longer loyal to their state or their actions are against the moral and legal principles upon which the state stands. Breach of allegiance through treason, acquiring the nationality of other/enemy state, or any other act against the state or its vital interests, voluntary relinquishment, terrorism, etc., are common grounds for the revocation of citizenship. But recent trends of revocation of citizenship have seen the politicisation of the practice. Rather than basing such criteria on the common interest of a state, the practice of revocation of citizenship has become subject to the interests of the people in power. There is no denying that matters of citizenship have a political dimension to them. Apart from the legal requirements of birth, domicile, marriage, or other connections, the status of citizenship revolves around a 'common identity' which the state accepts as a basis of citizenship and overall national identity. States

\footnotetext{
54 UN Human Rights Council, Arbitrary Deprivation of Nationality: Report of the Secretary-General, 26 January 2009 (n 33) [68].
} 
are usually formed surrounding that common identity, and although several states allow people of a different nationality and identity to be nationals even when not sharing such a common identity, ${ }^{55}$ many others strictly adhere to this identity as a requirement for citizenship. Liberia, for example, confers nationality on the basis of race. ${ }^{56}$ While such practices of bestowing citizenship based on race, religion, ethnicity, etc., have prevailed for a long time and will continue to do so, the action of disenfranchising a portion of the population and stripping it of nationality through a sudden change in the criterion of citizenship is clearly unjustified. An example of such arbitrary practice is the Citizenship (Amendment) Act, 2019, of India, which is discriminatory towards the people of a particular religion, ${ }^{57}$ although religion has never been the criterion of citizenship in India. ${ }^{58}$ Citizenship laws can be modified and amended to correct a prevailing injustice. But stripping individuals of their citizenship through such modifications, whose families have been the citizens of that state for past generations, is a gross human rights violation. Change in the citizenship laws must be for the greater interest of the state and for the enforcement of law and order. It is obligatory that such change takes into account the considerations of human rights. It is the citizens who participate in the democratic decision-making process of the country. This particular feature of citizenship provides an incentive for despotic regimes to enact unjustified and discriminatory criteria to strip nationality to best serve their political goals. Automatic loss of citizenship does not provide the sufferers with any chance to overturn the decision, giving the decision-makers absolute power to strip an individual of their most important status. This process, thus, legally 'dehumanises' an individual. Therefore, such practice is against morality, natural justice, and the constitutional norms of every civilised state and international law. The Liberian Supreme Court, by upholding the constitutional norms of Liberia, has indeed abided by the international human rights.

\section{Conclusion}

Restricting the discretion of states to regulate the modes of acquisition or revocation of citizenship by international law will surely limit a state's sovereign right regarding nationality. But it is important that state discretion in the case of nationality upholds the overall human rights of individuals. As prohibition against the arbitrary deprivation of nationality is an absolute necessity, states should abolish the practice of automatic loss of citizenship for good. In these troubled times, with evolving complex issues surrounding nationality, it will not be easy to ensure due process of law entirely. With a growing number of countries revoking citizenship due to

\footnotetext{
55 Marriage, residency, investment, etc., are common grounds on which nationality can be bestowed upon an individual who does not share the identity upon which citizenship is bestowed in a given state.

56 Aliens and Nationality Law (n 4) section 20.1(a).

57 The Citizenship (Amendment) Act, 2019, No. 47 of 2019, section 2.

58 To understand the construction of citizenship in India, see Joya Chatterji, 'South Asian Histories of Citizenship: 1946-1970' (2012) 55(4) The Historical Journal 1052-1054.
} 
involvement in terrorism, at times it will be either impossible or impractical to hold a hearing to revoke citizenship. Recently, the United Kingdom Court of Appeals, in a question regarding whether an individual who was stripped of citizenship due to joining ISIS could enter the United Kingdom to pursue her appeal before the Special Immigration Appeals Commission against deprivation of citizenship, opined against a blanket determination that the interest of national security outweighed the fundamental right to a fair and effective appeal. ${ }^{59}$ Thus, even in extraordinary circumstances, procedural due process should not be compromised.

Publisher's Note Springer Nature remains neutral with regard to jurisdictional claims in published maps and institutional affiliations.

59 See Shamima Begum v Special Immigration Appeals Commission (SIAC) (2020) EWCA Civ 918. However, in February 2020, the UK Supreme Court ruled that Shamima Begum would not be allowed to return and fight her citizenship case. 